\title{
LEI DA COMPOSTAGEM E PARTICIPAÇÃO SOCIAL: ETNOGRAFANDO POLÍTICAS PÚBLICAS EM FLORIANÓPOLIS/SC
}

\author{
Rianna de Carvalho Feitosa ${ }^{1}$ \\ Maristela Oliveira de Andrade ${ }^{2}$
}

\section{Introdução}

Antropoceno é um dos nomes propostos para definir uma nova era geológica, marcada pelo papel central da humanidade na geologia e ecologia da Terra. É definido como o período no qual o ser humano se torna um agente ecológico global, começando a impactar o sistema planetário (Pádua, 2015-2016). Sendo assim, compreendemos que grande parte dos impactos ambientais negativos que observamos atualmente são resultados de alterações antropogênicas, alterações que têm origem na atividade humana e, mais especificamente, na atividade humana inserida no regime capitalista de produção, que se baseia numa lógica acumulativa e consumista pautada na exploração de seres humanos e não-humanos e dos recursos naturais (Marques, 2015; Rial, 2016).

Luiz Marques, em seu Capitalismo e Colapso Ambiental (2015), aponta que a apropriação humana do mundo gera resíduos, lixo, do tipo industrial e em escala industrial. O lixo, segundo Marques, é produzido em todas as etapas do que ele denomina "ciclo produção-consumo". Isso causa intoxicação e empobrecimento dos ecossistemas também em escala industrial. Considerando a magnitude desses impactos, compreendemos a coleta e gestão de resíduos sólidos urbanos (GRSU) como uma das mais importantes atribuições dos municípios, constituindo uma política pública de cunho ambiental que tem preocupado não só pesquisadores, mas também grupos de ativistas e a sociedade em geral.

Em algumas cidades a participação social no processo de desenvolvimento e implementação de políticas públicas mostra-se mais destacada do que em outras. Foi a participação social ${ }^{3}$ o critério de escolha do município de Florianópolis para realização

1 Universidade Federal do Rio Grande do Norte, Brasil. E-mail: riannadecarvalho@gmail.com ORCID id: https://orcid.org/0000-0001-6792-2489

2 Universidade Federal da Paraíba, Brasil. E-mail: andrademaristela@hotmail.com ORCID id: https://orcid.org/0000-0001-7393-3977

3 Notório engajamento da população na gestão comunitária de resíduos, em compostagem comunitária, em movimentos em defesa da agroecologia e participação em ações pontuais em prol do meio ambiente, 
desta pesquisa, que busca evidenciar a relação histórica dos moradores da cidade na luta pela institucionalização de políticas públicas e investimentos em formas apropriadas de lidar com o lixo urbano. Destarte, interessamo-nos por compreender o contexto e os avanços da gestão de resíduos sólidos (GRS) no município de Florianópolis/SC, pontuando a importância da participação social em algumas decisões relevantes quanto à gestão de resíduos na capital; caracterizar a participação histórica da população do município em assuntos que envolvem as questões ambientais; e, por fim, acompanhar e analisar os debates ocorridos em sessões da Câmara Municipal dos Vereadores de Florianópolis (CMVF), que culminaram na aprovação do PL 17.506/2018 e, posteriormente, na aprovação e sanção da Lei 10.501 de 8 de abril de 2019, que ficou conhecida como Lei da Compostagem - a primeira lei no Brasil a dispor sobre a obrigatoriedade da reciclagem de resíduos sólidos orgânicos ${ }^{4}$.

Para o resgate histórico das ações da prefeitura em relação ao lixo, realizamos uma pesquisa bibliográfica e documental em sites da Prefeitura Municipal de Florianópolis e da Autarquia de Melhoramentos da Capital - Comcap (empresa responsável pela limpeza urbana), em documentos legais oficiais, em jornais da cidade, e em pesquisas acadêmicas sobre o tema. Realizamos também uma visita à Comcap e uma entrevista com um de seus funcionários, que nos apresentou o funcionamento da coleta, tratamento e recuperação dos RSU do município.

A pesquisa etnográfica partiu de narrativas de experiências etnográficas, tendo como inspiração alguns recursos antropológicos desenvolvidos por autores da escola de Manchester, como a análise situacional de Van Velsen e Gluckman (1986, 1986), desenvolvida para realizar estudo e análise de situações de mudança social, levando em conta tensões e contradições observadas nos eventos presenciados. A descrição e análise etnográfica dos eventos que precederam a sanção da Lei da Compostagem pela prefeitura foram baseadas na observação de duas sessões plenárias, ocorridas na CMVF nos dias 25 e 26 de fevereiro de 2019, respectivamente o primeiro e o segundo dia da votação do projeto de Lei (PL) que deu origem a lei posteriormente aprovada, o PL

realizadas por entidades públicas e privadas da cidade (cf. de Carvalho, 2020, onde há melhor explicação e indicação da existência de circuitos ambientalistas em Florianópolis).

4 Resíduos orgânicos são resíduos de origem animal ou vegetal, como restos de alimentos, casca e bagaço de frutas e verduras, ossos, casca de ovo, madeira, galhos secos, grama e folhas de poda etc. Esses resíduos são facilmente decompostos, podendo ser reciclados através de processos como compostagem e biodigestão. A sua disposição em aterros sanitários não é recomendada, pois em tal ambiente passam a se decompor de forma anaeróbica, gerando mau cheiro, atraindo organismos indesejados e emitindo gases perigosos para a atmosfera, além de prejudicarem diretamente a saúde pública. 
17.506/2018, de autoria do vereador Marcos José de Abreu, conhecido como Marquito. Começaremos por uma reflexão dos múltiplos significados adquiridos pelos termos que perpassam o núcleo desta pesquisa, ou seja, o lixo e seus desdobramentos através da sua apropriação pelos movimentos sociais e pelas políticas públicas.

\section{De lixo a lixo zero}

Antes de tudo, faz-se necessário explicar o que entendemos quando falamos em lixo. Consideramos o termo lixo problemático, por não discriminar a natureza do que está sendo rejeitado (não especificar seu caráter orgânico ou inorgânico, sua reciclabilidade, possibilidade de reaproveitamento ou de reúso etc) e desconsiderar a possibilidade de retorno desse material à cadeia produtiva. A dificuldade em categorizar o lixo se dá pelo fato de, na maior parte das vezes, o que é chamado de lixo ser um material heterogêneo, misturado, constituído pela combinação de diferentes elementos, sendo parte deles orgânica, outra inorgânica, alguns produzidos a partir de recursos naturais não renováveis. Alguns desses materiais teriam a capacidade de ser reutilizados ou reciclados, já outros podem apresentar componentes potencialmente tóxicos, precisando de um manejo específico. Essa complexidade torna o lixo um material muito difícil de ser manipulado, separado ou decomposto.

$\mathrm{Na}$ "natureza" não haveria lixo, porque aquelas substâncias que são produzidas pelos seres vivos e que precisam ser descartadas (como fezes e urina ou os restos de diferentes organismos depois de mortos) passam por um processo natural de reciclagem por meio da ação de seres decompositores - capazes de transformar matéria orgânica em minerais que, por sua vez, podem ser assimilados pelas plantas, produtoras de matéria viva. Assim sendo, o lixo é um produto exclusivamente humano, resultado da forma como consumimos e como lidamos com os resíduos na fase pós-consumo. A mistura disforme de resíduos tende a ser desvalorizada, por isso, procuramos deixá-lo o mais longe possível do nosso nariz e dos nossos olhares. Ele é culturalmente considerado indesejado, feio, impuro, sujo, repugnante (cf. Douglas, 1991; Serres, 2006).

A gestão de resíduos sólidos é um serviço prestado pelos municípios e sua eficiência depende não apenas das empresas que executam a coleta, mas da participação social através da coleta seletiva com a separação dos resíduos sendo feita na fonte geradora, as casas, os estabelecimentos públicos e os estabelecimentos comerciais. No 
artigo $9^{\circ}$ da Lei $N^{o} 12.305 / 2010$, que institui a Política Nacional de Resíduos Sólidos, há uma hierarquia recomendada para a gestão de resíduos. A lei prescreve que "[n]a gestão e gerenciamento de resíduos sólidos, deve ser observada a seguinte ordem de prioridade: não geração, redução, reutilização, reciclagem, tratamento dos resíduos sólidos e disposição final ambientalmente adequada dos rejeitos ${ }^{5}$ ". Prevenir e reduzir a geração de resíduos encontram-se no topo da hierarquia, portanto são as opções preferenciais. Logo adiante vêm a reutilização e a reciclagem, seguidas pela recuperação (tratamento). Já a disposição final ambientalmente adequada aparece como última opção sugerida para a destinação dos RSU, devendo ser interpretada como uma opção a ser evitada.

Em 04 de junho de 2018 foi publicado no Diário Oficial do Município de Florianópolis o decreto $\mathrm{n}^{\mathrm{o}}$ 18.646, que institui o Programa Florianópolis Capital Lixo Zero, o que faz da cidade de Florianópolis a primeira do Brasil a aspirar a tal denominação. Lixo zero ou desperdício zero (do inglês zero waste) é uma estratégia que pretende reduzir ao máximo a quantidade de resíduos sólidos que são encaminhados para aterros sanitários ou usinas de incineração, defendendo como alternativas a compostagem, reciclagem, reaproveitamento ou simplesmente a não geração de resíduos.

O programa visa, através de ações que envolvem a iniciativa privada, o poder público e a sociedade civil, incentivar a não produção ou redução da geração de resíduos sólidos urbanos, promovendo a valorização desses resíduos e a sua reintrodução na cadeia produtiva. Possui como meta desviar $60 \%$ dos resíduos secos e $90 \%$ dos resíduos orgânicos da destinação final em aterros sanitários até o ano de 2030. Entre as ações voltadas para o alcance das metas do lixo zero estão as voltadas para a compostagem dos resíduos orgânicos, que seja o foco deste artigo. Mas, antes disso, buscaremos compreender o contexto histórico que possibilitou o desencadeamento de ações que tornaram possível que uma lei inovadora como a Lei da Compostagem fosse aprovada no município de Florianópolis.

5 Rejeitos são aqueles "resíduos sólidos que, depois de esgotadas todas as possibilidades de tratamento e recuperação por processos tecnológicos disponíveis e economicamente viáveis, não apresentem outra possibilidade que não a disposição final ambientalmente adequada" (Brasil, 2010, art. $3^{\circ}, \mathrm{XV}$ ). 


\section{O lixo e as políticas ambientais em Florianópolis/SC}

Para desenhar o contexto do lixo em Florianópolis, mostrando um pouco sobre a história da gestão de resíduos sólidos na cidade ao longo dos anos, faremos um relato de como ela foi se modificando, muitas vezes, devido às intervenções feitas pela própria população da cidade, através de movimentos sociais.

Não havia ocupação urbana intensa no território que hoje é chamado Florianópolis até meados do século XVIII, quando imigrantes das ilhas de Açores e Madeira, parte do domínio da Coroa Portuguesa, fixaram-se na Ilha de Santa Catarina (Cabral, 1979; Piazza, 1994; Müller, 2002). No século XIX, Desterro, como Florianópolis era chamada na época, tornou-se capital da então província de Santa Catarina. Com o crescimento populacional e a construção de um porto, edifícios públicos e outras obras urbanas, o lixo começa a ser visto como um problema. Ao longo dos anos promoveram-se diferentes tratamentos aos resíduos sólidos gerados no território: foram jogados ao mar, enterrados nas praias, incinerados, depositados em um lixão em região de mangue e, finalmente, encaminhados para um aterro sanitário, em um município vizinho (Müller, 2002; Florianópolis/Comcap, 2012; Bagnati e Abreu, 2015).

Segundo arquivos encontrados no site da Prefeitura Municipal de Florianópolis (Florianópolis/Comcap, 2012) que traçam uma linha do tempo da limpeza pública na cidade, em 1830 havia uma lei que determinava que o lixo urbano fosse lançado nos rios e no mar - isso evitaria que os detritos se acumulassem em ruas e terrenos baldios da cidade. Na obra Nossa Senhora do Desterro, de 1979, escrita pelo historiador Oswaldo Rodrigues Cabral, há uma descrição do tratamento dado ao lixo nessa época:

Os primeiros edificadores desta cidade colocaram as casas com a frente para a terra e a parte posterior sobre o mar, de maneira que não havia passagem para a praia. Que significava tal coisa? Que os moradores consideravam um verdadeiro conforto terem o mar ali, à mão, para nele fazerem os seus dejetos... Bastava abrir a porta ou janela, esticar o braço e jogar ao mar toda a imundície da casa. Lixo, fezes... Praia era lugar de despejo, de cachorro morto, de lixo, lugar onde se derramavam vasilhas de matéria fecal, para que tudo se diluísse na maré, para que tudo desaparecesse no refluxo. (Cabral, 1979: 169-206).

Gláucia Müller (2002) aponta que nas cidades litorâneas, o hábito de jogar dejetos ao mar era muito frequente e as praias se tornavam verdadeiros lixões. O hábito era tão normalizado que, em 1855, a Câmara Municipal de Desterro construiu três pontes de madeira que adentravam o mar e para se despejar lixo e dejetos. No século XIX a relação com as praias era diferente, o banho de mar vindo a tornar-se comum 
apenas no século seguinte (cf. Rial, 1988). Conforme Corbin (1989), o imaginário ocidental das praias era marcado pela insalubridade o que explica esta desvalorização. Autoras como Carmen Rial (1988) e Gláucia Müller (2002) apontam que essas características culturais das cidades litorâneas brasileiras influenciaram a malha urbana, definindo a posição das casas, que eram construídas com suas entradas voltadas para o lado contrário ao mar. Tal disposição pode ser observada ainda hoje em locais como Ribeirão da Ilha, o segundo distrito mais antigo de Florianópolis que ainda mantém muito de seu conjunto arquitetônico preservado, traços da colonização portuguesa e cultura açoriana.

A dinâmica da cidade permaneceu assim até 1877, quando, como registraram Bagnati e Abreu (2015), a Câmara teria concedido o primeiro serviço de coleta e destino do lixo da cidade - que, apesar de continuar tendo o mar como destino, passou a ser jogado em áreas periféricas. No início do século XX foi construído um incinerador próximo ao local onde hoje se encontra a cabeceira insular da Ponte Hercílio Luz, que liga a Ilha de Santa Catarina à parte continental de Florianópolis. Com esse novo serviço, os resíduos produzidos na cidade passaram a ser recolhidos diariamente (Müller, 2002; Bagnati e Abreu, 2015). Um jornal da capital, o semanário O Olho, trouxe uma matéria intitulada "Forno de incineração" em 29 de maio de 1916, onde podemos ler:

O forno de incineração do lixo, contractado com o sr. Alexandre Villa, em Junho de 1911, quando o Superentendente Municipal o sr. Coronel Antonio Pereira da Silva e Oliveira, actual Vice-Governador do estado, é uma obra que muito contribuio para o saneamento de nossa bela Capital. O forno que está localizado em ponto afastado do centro da cidade, obedeceu em sua construcção a todos os requisitos exigidos pela hygiene (O Olho,1916).

Essa solução foi considerada avançada para a época e o forno funcionou por quase 50 anos, entre 1914 e 1958. Apesar de ainda não haver o número de pesquisas científicas que há hoje apontando os malefícios causados pela incineração de lixo - tais como a emissão de gases intensificadores do efeito estufa e de dioxina, um composto químico altamente tóxico e cancerígeno - na medida em que a cidade foi crescendo, a população começou a se incomodar com a fumaça gerada (Bagnati e Abreu, 2015).

Como consequência da insatisfação popular, a partir de 1956 começou-se a depositar o lixo da cidade no manguezal do Itacorubi, um bairro, naquela época, afastado do centro urbano. Acerca deste fato, durante uma visita que fizemos à 
Comcap $^{6}$, a empresa pública que é hoje responsável pela coleta e gestão de resíduos sólidos da capital, um funcionário, Ricardo da Conceição, contou-nos:

[...] o Itacorubi passou a ser uma parte símbolo do lixo de Florianópolis. Por quê? Porque na década de 50,1950... lá por volta de 1954, 1956, foi criado o lixão de Florianópolis. Exatamente aqui, onde vocês estão pisando. Naquela época, não tinha muito essa ideia do belo, do paisagístico. Não se trabalhava com essa ideia de proteger o meio ambiente, a biodiversidade... o conceito, a visão, era outra. E aí eles colocavam o lixo aqui. Porque era muito longe do núcleo da cidade, onde tinha mais população e onde funcionavam os serviços mesmo. Então aqui era como se fosse uma extremidade bem longe da Florianópolis, da "civilização de Florianópolis", né? (Ricardo da Conceição, sede da Comcap, 07 de março de 2019).

O Itacorubi era afastado do centro da cidade e ainda mantinha suas características rurais. Segundo apontado por Marius Bagnati e José Luiz Abreu, o mangue do Itacorubi era visto como "um local pestilento, úmido e aterrá-lo com 'lixo', no entendimento dos administradores daquela época, seria uma forma de recuperá-lo" (Bagnati e Abreu, 2015: 421-2). Explicam também que, àquela altura, não se conhecia ainda a importância dos mangues como área de amortecimento das marés e como berçários da vida marinha, nem se levavam em consideração os danos que a deposição de resíduos poderia causar à flora e fauna da região. Alguns anos antes, em 1925, o Itacorubi já havia recebido o Cemitério Municipal. O lixão se formou em uma área de aproximadamente 12 hectares, em frente ao cemitério.

Também colocaram aqui um cemitério, né, criaram um tripé de coisas que a gente
quer longe da gente... Assim como a gente pega o nosso lixo e coloca fora de casa,
porque a gente não quer dentro de casa [...], criaram esse tripé de coisas que a
sociedade rejeita: o lixo, que fede e cheira ruim; bandido que a gente não quer perto
da gente (também colocaram o presídio longe); e [o cemitério], as pessoas que estão
mortas, porque ninguém quer os mortos muito perto da gente também. E aí vieram
tudo pra essa área aqui do Itacorubi...(Ricardo da Conceição, sede da Comcap, 07
de março de 2019).

Nessa fala de Ricardo ficam claras as interpretações apontadas por Mary Douglas em seu clássico Pureza e Perigo (1991 [1966]). Douglas esclarece que tendemos a rejeitar, por considerarmos impuro, aquilo que não conseguimos compreender; rejeitamos o que nos parece obscuro ou contraditório, o que temos dificuldade em classificar. Esse é, muitas vezes, o caso do lixo, pois é algo misturado, que não conseguimos definir muito bem o que é. Além disso, ele possui a característica de adentrar, pouco tempo depois que é rejeitado e começa a sofrer com as intempéries, o espaço transitório que é a decomposição, se tornando uma massa disforme, que não é

6 A visita ocorreu em 07 de março de 2019, durante o "tour lixo zero", atividade promovida pelo Instituto Lixo Zero Brasil, que atendemos por ocasião de nosso trabalho de campo para escrita de uma dissertação de mestrado. 
nem uma coisa e nem outra. É compreensível que o desconhecimento sobre os materiais que compõem o lixo e seu processo de decomposição cause o estranhamento que resulta no ato de repelir, querer distante de si.

O lixão do Itacorubi funcionou por mais de trinta anos, sendo a disposição no mangue sempre feita de maneira inadequada, i.e., não houve impermeabilização do solo, não existia drenagem de chorume nem do gás gerados, acarretando problemas sérios de saúde pública e de degradação do mangue (Oliveira e Lopes, 1997). Bagnati e Abreu notam que, desde a colonização até aquele momento, os diversos fins que se escolheram para os resíduos poderiam se resumir a colocar o lixo "longe dos olhos e dos narizes ofendidos" (2015: 422), sem realmente haver uma preocupação quanto às consequências que as decisões acarretariam. Os mesmos autores sugerem que uma mudança de atitude por parte da população florianopolitana apenas se deu por causa do contexto político que o Brasil viveu na segunda metade do século XX, com o regime militar e o consequente desponte de movimentos populares, que tiveram parte na redemocratização do país. Apontam que esses fatos estariam intrincados ao início da discussão pública acerca do lixão:

Um dos movimentos sociais que se destacava em Florianópolis era o "Movimento
Ecológico Livre" (MEL), que surgiu em meados de 1983, atuando na defesa do
meio ambiente da capital catarinense, com destaque à proteção do Mangue do
Itacorubi. Este movimento professava os princípios do movimento ecologista
internacional e, juntamente com lideranças comunitárias, defendia o fechamento do
"lixão". A administração do município que tomou posse em 03 de janeiro de 1986,
apostou em uma mudança cultural em relação ao "lixo" e, já nos encontros
preparatórios para o início de sua administração, se discutia a viabilidade da
instalação de uma planta de reciclagem na cidade, em que os resíduos secos
pudessem ser separados dos orgânicos e estes compostados. Foi constituída uma
comissão multidisciplinar composta por técnicos da Prefeitura, a Companhia
Melhoramentos da Capital (Comcap) e a Universidade Federal de Santa Catarina
(UFSC), com o objetivo de discutir e definir estratégias para os problemas de
saneamento que a cidade enfrentava. Esta comissão foi dividida em diferentes
segmentos, sendo um deles denominado "Comissão do Lixo". (Bagnati e Abreu,
2015: 422).

A partir de 1989, em razão da pressão popular, iniciou-se a desativação do lixão, com seu uso sendo limitado ao enterramento de materiais inertes. A área aonde funcionava o lixão foi formalmente cedida pela União à municipalidade em 2013, mas desde o início dos anos 2000, com o aumento da produção de lixo em Florianópolis, passou a abrigar CETReS - Centro de Transferência de Resíduos Sólidos da Comcap, já que a empresa buscava uma estrutura que suportasse as diversas etapas que compõem a transferência do lixo ao seu destino final. Desde 1986, a Comcap, que havia sido criada em 1971, já realizando a limpeza da capital, passou a promover ações que visavam 
mudanças em relação ao manejo, tratamento e destinação dos resíduos: foram iniciadas as primeiras experiências de coleta seletiva na cidade que culminaram, nos anos seguintes, no Projeto Beija-Flor, que procurava tratar e destinar os resíduos nas próprias comunidades onde o projeto se inseriu, sendo o primeiro ensaio, no país, do que viria a ser a coleta seletiva de porta em porta (Florianópolis/Comcap, 2012).

O lixão do Itacorubi só foi completamente desativado em 1994, com a instalação do aterro sanitário em Biguaçu, município vizinho, mas desde 1990 o lixo gerado pela capital passou a ser enviado para o aterro. No mesmo período, iniciou-se a expansão da coleta seletiva por todo o perímetro urbano que atendia em torno de $60 \%$ da população do município e recolhia em torno de 60 toneladas de resíduos recicláveis por semana. Por duas vezes, nos anos de 2013 e 2016, a Prefeitura de Biguaçu ameaçou proibir a entrada de lixo provindo de Florianópolis no aterro do município. Na primeira vez, em novembro de 2013, a proibição aconteceu depois que a Fundação Municipal do Meio Ambiente de Biguaçu questionou a ausência do pagamento da Taxa de Fiscalização de Aterro por parte da prefeitura de Florianópolis à Proactiva (empresa responsável pelo aterro) que repassaria o valor a Biguaçu. $\mathrm{O}$ valor devido correspondia a $\mathrm{R} \$ 5,00$ por tonelada depositada no aterro e o conflito se resolveu quando a própria Proactiva resolveu saldar o débito com a prefeitura de Biguaçu (ND+, 2013). Na segunda vez, caminhões da Comcap foram impedidos de entrar no local devido a uma dívida em torno de R\$ 3 milhões, referente à ausência do pagamento da Taxa de Preservação Ambiental ao município (FloripAmanhã, 2016).

Essas inadimplências e omissões em relação à sanidade ambiental de Biguaçu que recebe, há décadas, a maior parte do lixo produzido na capital catarinense e em vários outros municípios vizinhos é questionável. Repetidamente se mobiliza a questão econômica, apontando todos os recursos financeiros que deixariam de ser gastos por Florianópolis caso houvesse grandes melhorias na gestão de resíduos da cidade, mas é essencial que se fale em um estímulo à proteção ambiental não só de seu território, mas também daquele que recebe tudo o que a capital considera impuro.

O destino do lixo da capital para outro município teria sido "terceirizado", segundo Oliveira e Lopes (1997). Os autores relembram um dos princípios da Convenção de Basiléia, que "Promulga o texto da Convenção sobre o Controle de Movimentos Transfronteiriços de Resíduos Perigosos e seu Depósito" (ICMBio, Decreto $n^{\circ} 875$, de 19 de julho de 1993). Embora a convenção internacional se refira a 
países, decretando que resíduos perigosos deveriam receber destino final no lugar onde foram gerados, os autores opinam que este princípio merecia ser aplicado também entre municípios de um mesmo país e que deveria se estender a todos os tipos de resíduos, não apenas aos perigosos (Oliveira e Lopes, 1997). Fazer com que o tratamento e deposição final dos resíduos acontecessem no local onde foram gerados poderia estimular uma reformulação do sistema atual, que impõe a outros o ônus do lixo não gerado por eles.

\section{PL 17.506/2018, o Projeto de Lei da Compostagem}

A seguir, procuramos realizar a análise antropológica de uma situação social, nos modelos que propõe Max Gluckman (1987). Focaremos, a partir de um evento observado, nas relações sociais estabelecidas e analisaremos as interações, desdobramentos, ambiguidades e influência mútua que os atores sociais presentes exercem uns sobre os outros. A observação de tais relações nos permitirá refletir sobre as inter-relações entre as demandas populacionais e sua consolidação em políticas sociais.

Analisaremos dois momentos de um evento único: o primeiro e o segundo dia da votação do projeto de Lei (PL) 17.506/2018, na Câmara Municipal dos Vereadores de Florianópolis. Apresentaremos o redator do PL, o vereador Marcos José de Abreu, do Partido Socialismo e Liberdade (PSOL), e as propostas do seu mandato - o gabinete agroecológico do PSOL, que propõe diversas ações relacionadas com a proteção do meio ambiente e lutas por justiça social e ambiental.

Segundo Hincapié (2015: 168), “as políticas públicas são processos socioculturais que interpretam, classificam e geram realidades". Compreender o processo de proposição da Lei da Compostagem e os processos complexos de articulação necessários para sua aprovação poderá ser importante para aprendermos mais sobre como se realizam as políticas públicas envolvendo a gestão de resíduos sólidos urbanos na cidade de Florianópolis.

As sessões plenárias da Câmara Municipal de Florianópolis (CMF) acontecem nas segundas, terças e quartas-feiras, entre as 16 horas e as 19 horas. Em geral, a ordem do dia e a pauta de requerimentos são publicadas com antecedência e encontradas muito facilmente na aba "Agenda" no site da CMF. Estava marcada para o dia 25 de fevereiro de 2019 a primeira votação do "Projeto de Lei da Compostagem", como o PL ficou 
conhecido entre os moradores do município. Tomei conhecimento sobre o Projeto de Lei e sua votação através das redes sociais de vereadores do município. Um convite informal realizado pela assessoria do autor do PL, em uma página do Facebook, dizia:

Depois de alguns entraves durante essa última semana nas sessões da Câmara, irá para votação o nosso tão sonhado Projeto de Lei 17.506/2018 que institui a obrigatoriedade da destinação ambientalmente adequada de resíduos sólidos orgânicos por meio dos processos de reciclagem e compostagem.

Este Projeto de Lei está em consonância com a Política Nacional de Resíduos Sólidos - PNRS (Lei 12.305 de 2010) que proíbe a destinação dos resíduos orgânicos e recicláveis aos aterros sanitários legalizados.

$\mathrm{O}$ projeto de lei indica que sejam consideradas as seguintes prioridades, como conjunto de propostas para resolver a gestão dos resíduos sólidos de forma integrada:

a) Compostagem comunitária - ex: Revolução dos Baldinhos;

b) Compostagem Institucional - Escolas e Postos de Saúde;

c) Incentivo de compostagem doméstica;

d) Pátio de Compostagem.

Anualmente, a cidade de Florianópolis envia cerca 93\% de todo o resíduo coletado para o aterro. Desse montante, 65 mil toneladas, o equivalente a $37 \%$ do resíduo produzido, corresponde à fração orgânica, com um gasto do poder público de $\mathrm{R} \$ 152,00$ por tonelada para o transporte e depósito no aterro sanitário. O Município gasta anualmente milhões de reais com esse transporte para o aterro!

Nós do mandato do Vereador Marquito defendemos uma gestão de resíduos sólidos descentralizada, especialmente nas comunidades periféricas, com participação social, focada na redução progressiva do envio desses resíduos para o aterro sanitário em Biguaçu [...]. (Abreu, 2019).

A criação do Projeto de Lei 17.506/2018, que indica a destinação ambientalmente adequada de resíduos sólidos orgânicos, estimulando processos de reciclagem e compostagem, é um passo de grande relevância e impacto na gestão de resíduos da cidade. No Brasil, cerca de $50 \%$ dos resíduos sólidos gerados são compostos por resíduos orgânicos. Em Florianópolis essa fração corresponde a cerca de 35\% do total de RSU produzidos (Florianópolis/PMCS, 2016).

Marcos José de Abreu, vereador autor do Projeto de Lei é engenheiro agrônomo e mestre em agrossistemas pela Universidade Federal de Santa Catarina (UFSC). Além disso, é coordenador de agricultura urbana do Centro de Estudos e Promoção da Agricultura de Grupo (a Cepagro), e foi responsável pela elaboração do texto da cartilha sobre compostagem lançada pelo Ministério do Meio Ambiente, intitulada Compostagem doméstica, comunitária e institucional de resíduos orgânicos: manual de orientação (Ministério do Meio Ambiente, 2017) ${ }^{7}$. Na cartilha que escreveu a convite do Ministério do Meio Ambiente, Marquito aponta:

[R] esíduos orgânicos têm um importante papel nos ciclos de nutrientes e destiná-los para aterros sanitários não só é um desperdício econômico como está em desacordo com a Política Nacional de Resíduos Sólidos (Lei nº 12.305/2010), que prevê que

7 Informações disponíveis em http://www.cmf.sc.gov.br/content/marquito-marcos-jose-de-abreu 
somente rejeitos devem seguir para disposição final. (Ministério do Meio Ambiente, 2017: 17).

No mesmo documento, define compostagem como:

[O] processo de degradação controlada de resíduos orgânicos sob condições aeróbias, ou seja, com a presença de oxigênio. É um processo no qual se procura reproduzir algumas condições ideais (de umidade, oxigênio e de nutrientes, especialmente carbono e nitrogênio) para favorecer e acelerar a degradação dos resíduos de forma segura (evitando a atração de vetores de doenças e eliminando patógenos). A criação de tais condições ideais favorece que uma diversidade grande de macro e micro-organismos (bactérias, fungos) atuem sucessiva ou simultaneamente para a degradação acelerada dos resíduos, tendo como resultado final um material de cor e textura homogêneas, com características de solo e húmus, chamada composto orgânico. (Ministério do Meio Ambiente, 2017: 25).

A Lei $n^{0} 12.305 / 2010$, que instituiu a Política Nacional de Resíduos Sólidos (Brasil, 2010), prevê que somente rejeitos devem ser enviados para disposição final em aterros sanitários. Os resíduos orgânicos, de maneira geral, são recicláveis por meio de processos como a compostagem e a biodigestão, portanto a sua disposição em aterros sanitários não é recomendada. É esse o caminho apontado pelo PL proposto pelo vereador, que procurou instituir uma lei que vetasse no município o encaminhamento desses resíduos para o aterramento, ressaltando as vantagens econômicas e ambientais da popularização e estímulo à compostagem (Ministério do Meio Ambiente, 2017).

Não obstante, este movimento não é algo inteiramente novo na capital catarinense. Segundo o Plano Municipal de Coleta Seletiva da cidade (Florianópolis/PMCS, 2016), Florianópolis já realiza reciclagem de resíduos orgânicos há quase trinta anos, tendo sido a prática da compostagem iniciada pela Comcap e PMF com o Projeto Beija-Flor ${ }^{8}$ e consolidada a partir do apoio do Departamento de engenharia Rural da UFSC, que contribuiu para difundir a compostagem em escolas, comunidades e instituições. Ademais, outras instituições, ONGs e empresas como Agroecológica, Composul, Pró Composto e Destino Correto se engajaram em promover a reciclagem de resíduos orgânicos (Florianópolis/PMCS, 2016). No mesmo documento são destacadas as seguintes práticas de compostagem na cidade:

8 O Projeto Beija-Flor foi um programa de tratamento descentralizado de resíduos em Florianópolis, que funcionou entre 1986 e 1994. Consistia na triagem domiciliar do "lixo" em secos, orgânicos e rejeitos. A fração orgânica passava a ser tratada no próprio bairro, através da compostagem, os resíduos secos eram comercializados e os rejeitos encaminhados ao ponto de coleta convencional mais próximo. Além disso, havia ações de educação ambiental voltada à população. O projeto foi aplicado em três locais, com perfis socioeconômicos diferentes: a comunidade Morro do Mocotó, de baixa renda e onde não havia sequer coleta de lixo; o Bairro Monte Verde, comunidade de renda média baixa e três prédios na Av. Jornalista Rubens de Arruda Ramos (conhecida como Avenida Beira-Mar Norte), área nobre da cidade, onde moram pessoas com alta renda (cf. Bagnati e Abreu, 2015). 
Pátio $\mathrm{CVR}^{9}$ - o Convênio entre a COMCAP, UFSC e Associação Orgânica desde 2008, realiza a compostagem de resíduos orgânicos em pátio de $4 \mathrm{mil} \mathrm{m}^{2}$ no CVR, localizado no bairro Itacorubi. São reciclados em torno de 03 toneladas de resíduos orgânicos por dia, cerca de 90 toneladas por mês.

FLORAM - Projeto Família Casca - surgiu em 2004 de uma parceria entre a FLORAM, Associação Orgânica e UFSC com apoio da COMCAP, e é desenvolvido no Parque Ecológico do Córrego Grande possuindo a seguinte estrutura: um PEV para receber resíduos orgânicos trazidos pela população e um pequeno pátio de compostagem. Atualmente o Projeto recebe aproximadamente $100 \mathrm{~kg}$ de resíduos orgânicos por dia ou cerca de três toneladas mensais.

SESC Florianópolis/ Cacupé - possui pátio de compostagem onde são tratadas em média uma (01) tonelada por dia, ou cerca de 30 toneladas por mês de resíduos sólidos orgânicos provenientes das unidades do SESC Estreito e SESC Prainha, bem como da própria unidade Cacupé que dispõe de Hotel e restaurante. Toda a poda de árvores e roçagem destas unidades também são utilizadas neste processo ${ }^{10}$.

Gestão Comunitária de Resíduos Sólidos Urbanos: o Projeto Revolução dos Baldinhos $-\mathrm{PRB}^{11}$ : teve início em outubro de 2008; os resíduos orgânicos separados são depositados em "baldinhos" e destinados aos PEV's distribuídos nas ruas da comunidade, coletados periodicamente e encaminhados para o Pátio de Compostagem; é modelo de gestão comunitária de Resíduos Orgânicos e Agricultura Urbana e em 2013 foi reconhecido pela Fundação Banco do Brasil como tecnologia social modelo para o país, pelo seu poder de replicabilidade em diferentes realidades e desde o início recebe acompanhamento técnico do CEPAGRO. (Florianópolis/PMCS, 2016: 7-8).

Como pudemos perceber, as iniciativas que incentivam e viabilizam a compostagem na cidade são várias. A presença desse tipo de prática local, cria um cenário favorável à proposta do PL que acompanharemos nos tópicos que se seguem.

\section{Primeiro dia de votação do PL da compostagem}

O PL 17.506/2018 ${ }^{12}$, que "dispõe sobre a obrigatoriedade da Reciclagem de Resíduos Sólidos Orgânicos no Município de Florianópolis" (Florianópolis/CMF, 2018) e que ficou conhecido pela população como "PL da Compostagem", foi apresentado à Câmara dos Vereadores em 15 de maio de 2018. O PL foi submetido a várias etapas de tramitação, sendo sua votação (feita em duas etapas) a última delas, que antecede o encaminhamento ao gabinete do prefeito. Este, por sua vez, pode sancionar ou não o projeto como Lei Municipal (LM). Após a redação do Projeto de Lei por parte do gabinete de um vereador ele é encaminhado para processamento, momento no qual precisa passar pela Consultoria Técnica e Parlamentar para que se obtenha a certificação

9 Centro de Valorização de Resíduos da Comcap.

10 Interessante apontar que Marquito foi o responsável técnico e idealizador do programa de compostagem da rede SESC de Santa Catarina.

$11 \mathrm{O}$ vereador Marquito também foi um dos colaboradores do projeto que deu início à Revolução dos Baldinhos, escrevendo sobre isso em dissertação de mestrado em agrossistemas, que teve como título "Gestão comunitária de resíduos orgânicos: o caso do projeto revolução dos baldinhos (PRB), capital social e agricultura urbana" (ABREU, 2013).

12 Documento original disponível em:

http://velho.cmf.sc.gov.br/proclegis/TextoOriginal/PL_17506_2018_Original.PDF 
da inexistência de uma LM sancionada ou em tramitação que já contemple as suas proposições. Além disso, são anexadas ao processo leis em vigor ou em tramitação que versem sobre temas semelhantes e ele passa pelas seguintes comissões: Comissão de Constituição e Justiça; Comissão de Trabalho, Legislação Social e Serviço Público; Comissão de Meio Ambiente; e Comissão de orçamento Finanças e Tributação, sendo avaliado e recebendo pareceres de cada uma delas. Cada comissão pode indicar admissibilidade ou inadmissibilidade do PL e propor alterações em sua redação. Caso os pareceres sejam favoráveis, a tramitação tem seguimento (Florianópolis/CMF, 2018).

O PL 17.506/2018 já havia passado por todas as tramitações acima descritas e a primeira votação no plenário estava prevista para compor a pauta da sessão ordinária do dia 25 de fevereiro de 2019. Fiquei sabendo mais tarde que a votação precisaria ser feita em duas etapas, para o caso de haver proposta de emendas por parte dos vereadores votantes, e que a segunda votação aconteceria no dia seguinte. Cheguei na Câmara dos Vereadores às 16 horas em ponto e a sessão já estava se iniciando. Havia um grupo considerável de pessoas na galeria, uma sala climatizada, ocupada por cadeiras do tipo longarina, almofadadas, e onde havia uma placa indicando que comportava até 26 pessoas. A galeria é separada do plenário (uma sala com um palanque, várias mesas, microfones e computadores, onde os políticos estavam) por uma estrutura de vidro transparente. Sentei junto ao público que estava na galeria.

Assim que cheguei, havia cerca de 10 pessoas na galeria. Ao longo das três horas de duração da sessão, entretanto, a sala ultrapassou seu limite de lotação (havia, como mencionado, assento para 26 pessoas e, em determinados momentos, estavam presentes pouco mais de 30), com períodos em que algumas pessoas precisaram ficar de pé, pois todas as cadeiras estavam ocupadas. Os presentes eram, em sua maioria jovens adultos, na faixa etária entre 20 e 40 anos, alguns (que vim a conhecer em outras ocasiões) estando associados a redes de ativismo, associações de bairro e movimentos ambientalistas da cidade.

Todos os que ali estavam pareciam ter ido para acompanhar a votação do PL da Compostagem - amplamente divulgada nas redes sociais do vereador Marquito. Era fácil perceber isso ao ler a reação do público (com aplausos ou com vaias) em relação a assuntos muito pontuais que eram tratados no plenário (sempre reagiam aos assuntos ligados a questões do meio ambiente) e pela movimentação para tirar fotos, gravar vídeos no celular ou levantar cartazes nos momentos em que Marquito tinha direito a 
voz. Os cartazes traziam frases que reforçavam a importância da aprovação do PL. Referenciavam o Projeto Revolução dos Baldinhos - uma experiência de gestão comunitária de resíduos orgânicos idealizada pelo vereador (num período anterior ao seu mandato) - e uma das mulheres trazia consigo plantas, que também usava para levantar e chamar a atenção dos políticos dentro do plenário.

A Câmara Municipal de Florianópolis possuía, em 2019, 23 vereadores (22 homens e 1 mulher). Ao início da sessão, menos da metade estava presente, mas aos poucos todos foram chegando. O presidente, Roberto Katumi, deu início à sessão, indicando quais seriam as principais pautas do dia e quais os Projetos de Lei e Resoluções seriam votados. Em seguida, disponibilizou para cada partido determinado tempo de fala, quando deveriam realizar seus apontamentos, declarações, apresentação de projetos e pedidos de resolução, organização ou foco em projetos já em andamento. A sessão variava entre momentos amistosos entre os vereadores e momentos de exaltação, nos quais alguns levantavam a voz e discordavam entre si. Na galeria, a plateia demonstrava interesse, parecendo achar tudo muito divertido.

Em determinado momento, o presidente da casa anunciou o início do tempo de fala do PSOL. Como os outros dois vereadores que compunham a bancada do partido escolheram não usar seus tempos de fala, concederam-se 2 minutos para Marquito, que assim iniciou seu discurso:

\footnotetext{
Senhores vereadores, senhor presidente, uma boa tarde! Queria também cumprimentar o público que acompanha aqui das galerias, um pessoal que, uma parte com certeza, veio acompanhar a tramitação e a votação do Projeto de Lei que incentiva a reciclagem e, especialmente, a compostagem no Município de Florianópolis. Um Projeto de Lei super importante, porque tem uma sociedade que consegue suportar e sustentar essa atividade. E, mais do que isso, nós temos hoje vários segmentos trabalhando com esse tipo de atividade - que é transformar o resíduo orgânico em adubo para as hortas, para os plantios em quintais, em hortas comunitárias, em centros de saúde, em escolas, [...] evitando que esse resíduo vá parar no aterro sanitário, [o que demanda] um alto custo!

Florianópolis produz 500 toneladas por dia de resíduos, em média. Mais de $40 \%$ desse montante é de resíduo orgânico. Nós pagamos um valor de $\mathrm{R} \$ 138,00$ por tonelada, só pra enterrar. Esse projeto que está hoje na ordem do dia, para a apreciação do plenário e para votação do plenário, é um projeto super importante e que qualifica todo o trabalho que a Comcap já faz de coleta e também qualifica toda uma ação comunitária que hoje tem em vários bairros de Florianópolis. [...] Eu cumprimento todos e todas que vieram apreciar hoje...que vieram acompanhar a sessão. É muito importante esse papel da participação nas nossas sessões. Que não fique só nesse Projeto de Lei, que vocês possam vir mais e mais vezes acompanhar o nosso trabalho aqui no parlamento municipal. E, mais do que isso, conheçam a nossa atuação e conheçam como que essas dinâmicas [funcionam] e como que a cidade é decidida três vezes por semana nesse plenário. Então, quero...[nesse momento o microfone é cortado]. (Marquito, Câmara dos Vereadores de Florianópolis, 25 de fevereiro de 2019).
} 
Os dois minutos de fala que haviam sido destinados para o vereador se esgotam e o microfone é imediatamente cortado. Nesse momento, as pessoas nas galerias se levantam e começam a aplaudir e levantar seus cartazes. Observando a movimentação, o presidente Katumi concede mais 30 segundos de fala e Marquito continua:

Quero cumprimentar a todas e a todos e dizer que a casa é nossa! Essa casa deveria estar muito mais receptiva, sem esse vidro, mas ainda é o que temos e, com certeza, o parlamento está aqui de braços abertos para todas e todos vocês. Valeu! (Marquito, Câmara dos Vereadores de Florianópolis, 25 de fevereiro de 2019).

Sublinhamos que Marquito fez questão de relembrar a todos da presença de seus apoiadores na galeria. Ele falou de forma entusiasmada sobre o PL de sua autoria e fez questão de apresentar dados concretos, com porcentagens e valores, que justificassem a importância do projeto, apesar de fazer confusão com alguns dos números (afirmou que o Município paga R\$138,00 por tonelada de resíduos enterrados e que "mais de 40\%" do resíduo produzido no município corresponde à fração orgânica, apesar de em outros momentos, como no convite do Facebook, ser apontado que o gasto é de R\$152,00 e que o montante é de 37\%). Fez, ainda, uma crítica branda ao distanciamento da população da cidade dos assuntos tratados por ele e pelos outros vereadores naquele espaço e ao formato não receptivo que ele apresenta.

Com o encerramento da fala, há mais uma salva de palmas na galeria. Quando se inicia o tempo do partido seguinte, Marquito deixa o plenário e vai até a galeria, cumprimentar aqueles que foram assistir à sessão. Ele se mostra simpático, agradece a presença de todos e se demora conversando com algumas pessoas que parecem amigas ou conhecidas. Marquito tinha cerca de 40 anos, mas aparentava ser um pouco mais jovem. No ambiente formal da Câmara dos Vereadores, ele se destacava. Possuía um cavanhaque e optava por manter o seu cabelo cacheado longo e solto. Falava de maneira mais informal (usando palavras como "galera" e "valeu") e, nessa ocasião, vestia uma calça roxa em conjunto com um paletó preto, gravata listrada em azul e vermelho e sapato azul, enquanto todos os outros usavam roupas em tons de preto e cinza ${ }^{13}$.

Os vereadores que estavam no plenário olhavam constantemente para a movimentação na galeria e o presidente da casa pareceu, em alguns momentos, incomodado com a presença de tantas pessoas. Não assisti a outras sessões plenárias além das duas votações do PL da Compostagem na CMF, mas não me pareceu ser comum um diálogo tão próximo nem a aproximação dos vereadores com o público das

13 Interessante apontar que, nas eleições de 2020, Marquito foi reeleito e foi o vereador mais votado de Florianópolis, com 5858 votos (NSC Total, 2020). 
galerias, como observei nesse dia. A sessão continuou com as falas dos vereadores de diferentes partidos, discutindo as pautas propostas por cada um, e foi se alongando sem mais mencionar o PL da compostagem, que deveria ainda ser votado. Quando já eram cerca de 18 horas (a sessão se encerraria às 19 horas), o vereador Marquito pediu a palavra, alegando questão de ordem, e se dirigiu ao presidente da casa solicitando que a votação de seu projeto de lei acontecesse. Ocorre, então, o seguinte diálogo entre vereador e presidente da casa:

[Marquito] Senhor presidente, é... eu... mesmo sabendo que não é o momento de pedir questão de ordem...

[Katumi] Então não faça!

[Marquito] Mas eu queria pedir a sua sensibilida...

[Katumi] Após, após!

[Marquito] Eu gostaria de pedir para que a gente votasse o Projeto de Lei da compostagem, é chamado assim...

[Katumi] Perfeito.

[Marquito] Em respeito ao público que está acompanhando a sessão e que gostaria de acompanhar a votação.

[Neste momento o público da galeria emite gritos e inicia uma salva de palmas, em tom de apoio].

[Katumi] É!... é muito bom quando a galeria tá cheia, fica muito fácil fazer isso aí!

[A galeria agora é um misto de aplausos e vaias]

[Katumi, em tom de reprovação] É brincadeira...

[Algumas pessoas na galeria respondem: "brincadeira é você nessa cadeira", "isso aqui é sério!", "para de enterrar dinheiro!". O presidente Katumi ignora e dá seguimento à sessão, chamando um novo vereador para usar seu tempo de fala]. (Diálogo entre Marquito e Katumi, Câmara dos Vereadores de Florianópolis, 25 de fevereiro de 2019).

Já faltando 15 minutos para o fim da sessão, Marquito pede a palavra mais uma vez e solicita que se faça a votação de seu PL. Sugere que, por falta de tempo, haja apenas a votação, sem a discussão do projeto. Propõe que a explicação do Projeto e as discussões sejam transferidas para o dia seguinte, quando se daria a segunda etapa da votação. Reconhecendo que realmente havia pouco tempo para realizar ambas as etapas (a votação e a declaração, por parte de cada vereador interessado, sobre a escolha do seu voto), o presidente da casa pergunta aos vereadores presentes se eles declinam seus pedidos de declaração de voto e, conseguindo autorização, permite que a votação aconteça. O público responde animado, com palmas e comemoração. É declarada 
“aberta a votação do Projeto de Lei 17.506/18, do vereador Marquito que dispõe sobre a obrigatoriedade da reciclagem de resíduos sólidos orgânicos no município de Florianópolis" e o presidente Katumi faz os encaminhamentos e outras declarações necessárias antes de solicitar aos vereadores que procedam com a votação nominal eletrônica.

Enquanto os vereadores iniciam a votação, feita de forma eletrônica, Marquito pede a palavra mais uma vez:

Só como um encaminhamento de voto, senhor presidente... Solicito o apoio de todo o plenário para a votação favorável desse Projeto de Lei que é tão importante para a cidade. A longo prazo, ele vai trazer muito mais ecologia para a cidade, muito menos custo e uma aliança com o trabalho de agricultura ecológica e agricultura urbana. A gente tá tratando hoje do resíduo orgânico como um problema, mas, na verdade, ele é um recurso [nesse momento Marquito é interrompido pelo presidente Katumi, que apressa os vereadores para realizarem suas votações e Marquito encerra:]... Peço um parecer favorável. É isso! Obrigado! (Marquito, Câmara dos Vereadores de Florianópolis, 25 de fevereiro de 2019).

Em seguida, solicita a palavra o vereador Rafael Daux, do MDB (Movimento Democrático Brasileiro), que, apesar do acordo pela não declaração de votos, assim se manifesta:

Presidente, por favor, presidente... Como o proponente do projeto falou, eu quero falar contra o projeto. Todos já pagam para a Comcap fazer esse serviço, e vem o PSOL querer obrigar as pessoas a fazerem o que a gente já paga pra que seja feito... [o vereador é interrompido pelo público na galeria que começa a se manifestar contra sua declaração, gritando "é mentira!", "tão enterrando dinheiro", "isso é interesse particular" e "quem é esse cara?!"]. (Rafael Daux, Câmara dos Vereadores de Florianópolis, 25 de fevereiro de 2019).

Em seguida, o Vereador Renato da Farmácia, do PL (Partido Liberal), também faz a sua declaração, apontando para o plenário que o projeto em votação não é um projeto apenas do vereador Marquito, mas que é um projeto para cidade, uma oportunidade para erradicar os terrenos baldios e os focos de dengue: "quando tem a oportunidade da gente melhorar isso, nós não podemos votar contra”. Renato é seguido pelo vereador Maikon Costa, do PSDB (Partido da Social Democracia Brasileira), que também defende o projeto, afirmando ser importantíssimo para a cidade. A plateia reage aos dois comentários, comemorando, com certa ironia, a última declaração, quando alguém fala "ganhasse um pontinho, hein, ganhasse uma estrela". Notando a movimentação e tom de deboche na galeria, o presidente Katumi reclama: “Ordem! Queria dizer para a galeria: concordamos com qualquer manifestação, mas o respeito ao voto livre de cada vereador deve ser também respeitado.” Em seguida declara encerrada a votação, o projeto tendo sido aprovado, contabilizando apenas dois votos contra. As 
pessoas na galeria começam a conversar entre si e desviam sua atenção do que acontece dentro do plenário. Pouco depois, Marquito aparece novamente na galeria para agradecer a todos e conversar com alguns. Enquanto isso, a sessão é encerrada na sala por trás do vidro.

Interessa-nos chamar a atenção ao diálogo sutil, porém constante, estabelecido entre a galeria e o plenário, a partir da reação do público da galeria ao que era falado na sala onde estavam os políticos e a resposta dos políticos à presença desse público tão afetado. Certamente a presença de apoiadores do PL em pauta contribuiu, se não para a sua aprovação, pelo menos para que sua votação realmente acontecesse na data planejada e para o posicionamento de alguns dos vereadores - que pareciam voltados a enfatizar o seu apoio ao projeto apenas ao compreender sua importância para os eleitores que estavam presentes.

\section{Segundo dia de votação do PL da compostagem}

A segunda etapa da votação do PL17.506/18 aconteceu na sessão ordinária do dia seguinte, 26 de fevereiro de 2019. A sessão se iniciou na mesma hora, 16 horas, mas, dessa vez, cheguei um pouco atrasada. Já havia plateia nas galerias, mas em número bem menor do que no dia anterior, e que não se alterou muito com o passar das horas. Mais uma vez, as primeiras duas horas da sessão foram dedicadas às discussões e requerimentos previstos na ordem do dia, havendo o encaminhamento da votação apenas com a aproximação das 18 horas. O presidente da casa, Roberto Katumi Oda, anunciou o Projeto de Lei como tendo sido aprovado no dia anterior com "pareceres favoráveis com emenda" e declarou aberta a discussão do projeto, chamando os vereadores que desejassem apresentar suas emendas e reflexões sobre a proposta.

O primeiro a falar foi Maikon Costa, do PSDB, que iniciou seus cinco minutos de fala parabenizando o vereador autor do projeto por, em tão pouco tempo naquela casa legislativa ${ }^{14}$, ter elaborado um projeto tão importante. Lembrou que teve "a felicidade e a honra" de ser relator, por duas vezes, daquele projeto, na comissão de Comissão de Constituição e Justiça e na Comissão de Meio Ambiente, e falou na importância de uma "cultura da reciclagem". Durante a sua fala, as pessoas tanto na galeria quanto dentro do plenário pareceram muito agitadas e dispersas, conversando entre si e fazendo muito barulho. Mesmo com a transmissão de sua voz via microfones, 
em alguns momentos foi bem difícil entender o que o vereador falava. Percebendo a agitação, o vereador interrompeu sua fala e pediu ao presidente da casa para que chamasse a atenção de seus colegas no plenário, para que fizessem silêncio e prestassem atenção. Retomando o pronunciamento, mencionou o papel importante da reciclagem dos resíduos orgânicos na redução do valor de quase $\mathrm{R} \$ 30$ milhões, que são gastos anualmente para enviar um "lixo que não é lixo" para os aterros sanitários. Ressaltou que a reciclabilidade dos resíduos orgânicos depende da obrigação de cada cidadão em separar os resíduos que produz, mas que o fato de cerca de R\$ 3 milhões ${ }^{15}$ estarem "sendo jogados no lixo" é responsabilidade, também, daqueles que não dão a devida atenção a um tema de tanta relevância, como é o caso de seus colegas no plenário:

Nem parece que temos 3 milhões de reais sendo jogados, literalmente, no lixo. Porque vocês não dão atenção, o plenário tá nessa situação... Senhor presidente! O senhor coloque ordem no plenário! O senhor é o ministro dessa sessão. Tá impossível, parece que as pessoas não se importam com um tema tão importante, tão relevante. (Maikon Costa, Câmara dos Vereadores de Florianópolis, 26 de fevereiro de 2019).

Maikon tem sua fala interrompida e, fora do microfone, um dos políticos que compõem a mesa responde: "Não é a oposição... a bancada governista tá toda te ouvindo! É o Pedrão, o Marquito...”. A mesa lhe concede mais dois minutos de fala. O vereador Pedro Silvestre, conhecido como Pedrão, do PP (Partido Progressista) pede tempo de fala para se explicar e apontar que estava, sim, prestando atenção ao que seu colega falava. O vereador Lino Peres, do PT (Partido dos Trabalhadores) também vem se desculpar pelo tumulto no plenário, falando sobre um problema interno que estavam buscando resolver.

Em seguida, Marquito é chamado para a discussão do PL. A mesa lhe concede dez minutos de fala. Nesse momento, tanto a galeria quanto o plenário já estão bem mais silenciosos do que quando Maikon falava. Marquito inicia:

Senhores vereadores! Senhor presidente! O público que acompanha também aqui nas galerias, quero cumprimentar a todas e todos! [...]

Esse projeto de Lei, ele tem uma importância super significativa. Primeiro porque a gente tá falando dos resíduos orgânicos que, hoje, compõem mais de $40 \%$ de todos os resíduos gerados na cidade de Florianópolis. A cidade de Florianópolis produz, diariamente, 500 toneladas de resíduos sólidos - em média! Porque nós temos os períodos de alta temporada em que [essa produção] chega a valores, a números, de quase mil toneladas/dia. [...]

Nós temos um valor pago especificamente para enterrar esse resíduo. É o valor pago chamado "transporte secundário". A Comcap e todos os trabalhadores da Comcap fazem todo o serviço de coleta em todos os bairros e levam para o Centro de

15 Há um equívoco no dado apresentado pelo vereador, já que em Florianópolis o valor gasto anualmente com o envio de RSU para o aterro sanitário aproxima-se de R \$ 30 milhões e não de R \$ 3 milhões (como ele próprio havia dito anteriormente). 
Transbordo, ali no Itacorubi. A partir dali $[\ldots]$ a empresa dona do aterro de Biguaçu faz o transporte secundário. Tira do Itacorubi e leva até o aterro sanitário de Biguaçu. Chegando lá, enterra.

Esse custo, hoje, é um valor de aproximadamente $\mathrm{R} \$ 138$ por tonelada, sendo que a gente produz uma quantidade significativa. O custo anual, só para enterrar lixo, é de R \$ 30 milhões, valor previsto na lei orçamentária anual. [...] É um custo altíssimo! É quase o mesmo orçamento que nós temos pra a pasta de assistência social do município. O mesmo valor que a gente paga pro aterro, a gente tem de orçamento pra assistência social! É quase o triplo do que temos para a pasta de esporte e cultura... vocês entendem a importância disso? (Marquito, Câmara dos Vereadores de Florianópolis, 26 de fevereiro de 2019).

Em seguida, Marquito apresenta a alternativa aos problemas apresentados, explicando que os resíduos que são enterrados poderiam se transformar em composto orgânico. Mostra, para que todos vejam, um saquinho com adubo que levou consigo para a tribuna, ressaltando que esse tipo de composto orgânico é a base de uma agricultura ecológica - uma das principais pautas de seu mandato. Relembra que o município tem gastos comprando terra adubada para a manutenção de canteiros e jardins públicos. Um custo, segundo ele, desnecessário, pois a demanda poderia ser suprida com a produção do adubo fruto da compostagem de resíduos orgânicos. Explica que a lei que está propondo pretende regrar o sistema de coleta em três frações: recicláveis secos, compostáveis orgânicos e rejeitos. Fala na análise gravimétrica feito pelo Plano Municipal de Coleta Seletiva, que mostra que menos de $25 \%$ dos resíduos produzidos pela cidade são rejeito.

O vereador, então, parabenizou o trabalho da Comcap, onde já existem pátios de compostagem, dizendo que muitos dos funcionários da empresa que estão dispostos a trabalhar com a técnica da compostagem são impedidos por falta de condições adequadas ou falta de manutenção das máquinas utilizadas. O seu projeto viria para corrigir isso, considerando criar, inclusive, um departamento de compostagem na Comcap, semelhante ao departamento de coleta seletiva já existente. Dessa forma, os resíduos passariam a ser vistos como recursos, abastecendo uma rede de agricultura agroecológica, urbana e periurbana na cidade.

Finalizando seu pronunciamento, o vereador indica que o que propõe é uma lei inédita, capaz de se tornar referência nacional e mundial, e que está em consonância com resoluções da atual administração do município, como o Decreto Lixo Zero e o decreto do Plano de Gerenciamento de Resíduos Sólidos ${ }^{16}$. Além disso, é uma lei que 
"atua na prática" e que dá condições para que "a Comcap seja protagonista nesse processo". Nesse momento, um outro vereador pede a palavra e sintetiza a longa fala de Marquito de modo poético, afirmando que "o aterro, que é a morte, se transforma em vida [...], gera alimentos e floresce a cidade como um todo... Então, o que era morte pode criar uma cidade verde". Marquito retoma a palavra, agradece, e pede pelo voto favorável de todos os vereadores.

Ninguém mais querendo se pronunciar, a votação do projeto é iniciada e, após um desentendimento entre Maikon Costa e o presidente Katumi (sobre a legitimidade das emendas apresentadas, o que termina com o presidente chamando a atenção de Maikon e o acusando de querer manchar a imagem da casa e desmoralizar o parlamento) é declarado que o projeto foi aprovado. Dessa vez, há pouca reação do público das galerias, que, além de estar mais quieto do que no dia anterior, parece ter sua atenção desviada para a intriga estabelecida entre o vereador Maikon e o presidente da casa. Os minutos seguintes da sessão se concentram em trocas de ofensas, ironias e gritos entre os dois políticos, chegando ao ponto do presidente decidir suspender a sessão, desligando todos os microfones do plenário e continuando a discussão, sem que a galeria e o público que acompanhava a sessão em transmissão ao vivo pudessem ouvilos.

Com o retorno da sessão, outros vereadores declaram seus votos, ressaltando a importância da aprovação do PL, indicando ser um marco para que se estabeleça uma "mudança cultural na cidade", para que Florianópolis "evolua em sua relação com o lixo" e deixe de lado o modelo ineficiente, caro e ambientalmente danoso que está em curso. Outro vereador faz votos para que "a prefeitura não se sinta dona do modelo", mas se reconheça apenas como gestora, sendo a população a verdadeira proprietária desta nova relação com os resíduos. Marquito agradece a todos que votaram de forma favorável ao projeto. Sublinha que não é um projeto dele, mas um projeto da cidade e relembra que a Prefeitura Municipal de Florianópolis recebeu um recurso de cerca de R\$ 1 milhão, do Fundo Nacional do Meio Ambiente para investir na estruturação da compostagem na cidade, com ações como a compostagem comunitária, o projeto Minhoca na Cabeça, a instalação de pátios comunitários e instalação de pátios na base da Comcap - um projeto que ele ajudou a redigir.

O projeto-piloto impulsionado pelo recurso de mais de R\$ 1 milhão do Fundo Nacional do Meio Ambiente implantou iniciativas que pretendem dobrar a quantidade 
de resíduos orgânicos desviados de aterro sanitário, que subiria de cinco para dez toneladas recuperadas por dia pelo Centro de Valorização de Resíduos (CVR) do Itacorubi. Em entrevista para o Diário Catarinense o atual presidente da Comcap, Márcio Luiz Souza, indica:

Em 2018 mandamos para o aterro 193 mil toneladas, então em torno de 20 mil toneladas são resíduos verdes que pagamos para enterrar em Biguaçu. Se conseguir desviar isso do aterro, será matéria prima para compostagem. Se recuperar também os restos de alimentos por meio da compostagem nas casas e nas comunidades, Florianópolis poderá deixar de mandar 27 caminhões de lixo por dia para o aterro. Além de diminuir o custo com aterro, passaremos a gerar mais renda para empresas, associações, famílias. (Diário Catarinense, 2019).

A sessão se segue com a votação de outros projetos de lei e é encerrada. Como no dia anterior, Marquito dirige-se às galerias para cumprimentar o público e agradecer pela sua presença. Fica evidente o reconhecimento que o vereador dá ao apoio popular oferecido durante a tramitação de seu projeto de lei. Conforme apontamos anteriormente, a participação social da população florianopolitana em eventos, ações e projetos ligados a sustentabilidade e gestão de resíduos é notória. Uma etnografia dos sujeitos da política pública, como aponta Liliana Hincapié (2015), permite que desenvolvamos reflexões sobre a forma como os movimentos sociais e as organizações pensam o Estado (e sua possibilidade de participação nele), assim como a maneira como o Estado e suas instituições e funcionários entendem a sociedade e seus problemas (o mesmo tempo em que se permitem influenciar pela sociedade e pelas respostas por ela exigidas e esperadas).

\section{Encaminhamentos posteriores às votações}

Após a aprovação na Câmara dos Vereadores do PL de autoria de Marquito, sobre a obrigatoriedade da compostagem no município, o projeto seguiu para a Prefeitura Municipal da cidade e foi sancionado como lei em 08 abril de 2019, pelo prefeito Gean Loureiro, sendo divulgada no Diário Oficial do Município como Lei $\mathrm{N}^{\circ}$ 10.501, de 08 de abril de 2019, na qual constavam alguns ajustes em relação ao Projeto que havia sido apresentado.

A nova lei teve 60 dias para ser regulamentada, sendo uma nova versão publicada no Diário Oficial do Município, sob o número 10.574 de 17 de julho de 2019, e alterando a Lei $\mathrm{N}^{0} 10.501 / 2019$. As alterações consistiram em adendos, previsão de situações de exceção e criação de um calendário de metas. Como no artigo segundo, que deliberava sobre ser "vedada, por força desta Lei, a destinação aos aterros sanitários e à 
incineração dos resíduos sólidos orgânicos no município de Florianópolis", à qual se acrescentou o seguinte trecho: "exceto nos seguintes casos: I -calamidade pública; II decreto do Poder Executivo declarando estado de emergência; e III -paralisação dos trabalhadores da Autarquia COMCAP superior a três dias." Deliberou-se o seguinte cronograma:

I - até 5 de junho de 2020, vinte e cinco por cento dos resíduos orgânicos devem ser obrigatoriamente destinados à compostagem;

II - até 5 de junho de 2021, cinquenta por cento dos resíduos orgânicos devem ser obrigatoriamente destinados à compostagem;

III - até 5 de junho de 2022, sessenta e dois vírgula cinco por cento dos resíduos orgânicos devem ser obrigatoriamente destinados à compostagem;

IV - até 5 de junho de 2023, setenta e dois vírgula cinco por cento dos resíduos orgânicos devem ser obrigatoriamente destinados à compostagem;

V - até 5 de junho de 2024, oitenta por cento dos resíduos orgânicos devem ser obrigatoriamente destinados à compostagem;

VI - até 5 de junho de 2025, oitenta e cinco por cento dos resíduos orgânicos devem ser obrigatoriamente destinados à compostagem;

VII - até 5 de junho de 2026, oitenta e oito por cento dos resíduos orgânicos devem ser obrigatoriamente destinados à compostagem;

VIII - até 5 de junho de 2027, noventa e um por cento dos resíduos orgânicos devem ser obrigatoriamente destinados à compostagem;

IX - até 5 de junho de 2028 , noventa e quatro por cento dos resíduos orgânicos devem ser obrigatoriamente destinados à compostagem;

X - até 5 de junho de 2029, noventa e sete por cento dos resíduos orgânicos devem ser obrigatoriamente destinados à compostagem; e

XI - até 5 de junho de 2030, cem por cento dos resíduos orgânicos devem ser obrigatoriamente destinados à compostagem. (Diário Eletrônico do Município de Florianópolis, 2019).

A partir da data de publicação, a lei teve o prazo de cento e oitenta dias para ser regulamentada pelo Poder Executivo, que poderia sugerir novas alterações antes de colocá-la em prática. A lei foi amplamente divulgada por diversos grupos ambientalistas da cidade após a sua sanção. O papel da população que acompanhou os trâmites de votação do PL na Câmara Municipal de Florianópolis foram de notável importância para a sua aprovação e demonstram o interesse e empenho dos moradores do município em ações ligadas à proteção do meio ambiente.

\section{Considerações finais}

Até o encerramento da escrita deste artigo, a Comcap é a empresa responsável por diversas atividades como coleta domiciliar de resíduos, coleta de lixos volumosos e pesados, coleta seletiva de materiais recicláveis, varrição das ruas, limpeza após eventos e festas populares, dentre outros. Os principais serviços são a coleta de RSU, havendo duas modalidades desse serviço: coleta domiciliar porta em porta e entrega voluntária de resíduos. Os resíduos devem ser colocados na rua na forma, dias e horários certos, 
conforte um roteiro preestabelecido e é imprescindível a colaboração dos geradores para que haja separação dos resíduos na fonte, i.e., é o gerador que escolhe qual destino terá o seu resíduo, se vai para a reciclagem ou se segue para o aterro sanitário.

No ano de 2018 a Comcap recolheu 209.318 toneladas de resíduos sólidos em Florianópolis, sendo 193.829 toneladas de rejeitos (encaminhados para o aterro de Biguaçu), 12.052 toneladas de recicláveis secos (que foram integralmente doados para associações de catadores) e 3.437 toneladas de recicláveis orgânicos (compostados pela própria Comcap). Como vimos, é bastante significativo o papel da Comcap na efetivação de políticas públicas que originam mudanças em relação a GRSU em Florianópolis. É muitas vezes através da Autarquia que tanto o governo quanto entidades da sociedade civil, grupos de interesse e movimento sociais concretizam seus propósitos. A autarquia confere suporte a projetos de educação ambiental ou destinação correta de resíduos, como no estabelecimento de parcerias com iniciativas que recolhem lixo eletrônico, óleo usado ou outros tipos de materiais específicos (como demonstraram de Lima e Guivant em artigo de 2016, sobre e-waste); e formas de suporte mais contínuo que dão respaldo a projetos comunitários como a Revolução dos Baldinhos e o Disco Xepa, como descreveram Schneider e Almeida (2016) em artigo sobre reutilização de resíduos orgânicos na capital catarinense. A partir da aprovação da Lei 10.501 de 8 de abril de 2019 a empresa assumirá mais uma importante função, tendo papel essencial na efetivação do recolhimento e compostagem dos resíduos sólidos orgânicos do município.

O problema do lixo é um problema estrutural, que afeta de maneira complexa as sociedades que o produzem. Por ser um problema complexo, exige soluções igualmente complexas. Apresentamos os esforços realizados pelo mandato agroecológico do PSOL na Câmara Municipal de Florianópolis. O mandato do vereador Marquito, além de questionar o modelo econômico vigente e lutar por diferentes causas socioambientais, foi capaz de propor e aprovar uma lei que, efetivamente, volta as políticas públicas do município em direção a melhorias quanto a gestão de resíduos sólidos urbanos. Ele se engaja na defesa de ideias como agroecologia e incentivo a hortas comunitárias e compostagem - caminhos capazes reduzirem drasticamente a produção de "lixo". Segundo a lei proposta, que trata do incentivo à compostagem de resíduos orgânicos, o município pode, até 2030, deixar de enviar toneladas de "lixo" para aterros sanitários. Os resíduos reaproveitados, então, transformam-se em adubo. 
Foi interessante, também, perceber o apoio de setores da população florianopolitana a esse projeto. Além da população, percebemos o apoio da prefeitura, especialmente através das ações realizadas pela Comcap, e de entidades empresariais.

Acreditamos ser relevante a reconstrução de um senso de comunidade na busca por mudanças sociais. Como aponta Hincapié (2015: 158):

[A]s políticas públicas são reconhecidas como produto de um processo sociocultural, que não é apenas técnico, [e] envolve não só os tecnocratas que a formulam e implementam, como, também, as pessoas que se beneficiam das políticas, os grupos de interesse e os movimentos sociais, entre outros. Assim, as políticas refletem formas de pensar sobre o mundo e de como nele atuar. Contêm modelos implícitos - e algumas vezes explícitos - de uma sociedade e de visões de como os indivíduos devem relacionar-se com a sociedade e uns com outros.

Ainda que global, a chamada crise ecológica manifesta-se especialmente em contextos locais, situados e específicos, a partir dos quais os grupos sociais, humanos e não-humanos, são confrontados com as demandas de um novo cenário ecológico em rápida transformação. Anna Tsing (2019) identifica tais ações locais de distintos grupos como modos de ocupar as ruínas do capitalismo, isto é, ações objetivando formas alternativas de manutenção social, produção, consumo e convivência com o ambiente. Para que essas mudanças socioculturais sejam efetivadas é preciso admitir que questões como consumo e descarte não são assuntos privados e que é importante se ter coragem para levar esse e outros assuntos para as arenas de disputas políticas. É importante assumir que manter um "estilo" ou "filosofia de vida" mais sustentáveis não é o bastante, muitas vezes não passando de vaidades pessoais, como criticou Ailton Krenak (2020). Apenas assumindo posicionamentos éticos e políticos em relação à forma de estarmos no mundo (e nos relacionarmos com os recursos naturais, com o planeta, com a natureza, com os animais) é que teremos chance de realizar mudanças concretas. 


\section{REFERÊNCIAS}

ABREU, Marcos José de. Votação do Projeto de Lei da Compostagem - segunda (25) - 16h. Florianópolis, 2019: Facebook. Disponível em: https://www.facebook.com/events/343119059635668/ Acesso em: 13 de set de 2019.

BAGNATI, Antonio Marius Zuccarelli; ABREU, José Luiz Crivelatti de. Programa Beija-Flor de Tratamento Descentralizado de Resíduos em Florianópolis-SC, Brasil. In: FRICKE, Klaus; PEREIRA, Christiane; LEITE, Aguinaldo; BAGNATI, Marius. (org.). Gestão sustentável de resíduos sólidos urbanos: transferência de experiência entre a Alemanha e o Brasil. Braunschweig: Technische Universität Braunschweig, 2015. Disponível em: https://goo.gl/BE246I Acesso em: set. de 2019.

BRASIL. Lei $\mathbf{N}^{\mathbf{0}} \mathbf{1 2 . 3 0 5}$, de 2 de agosto de 2010. Institui a Política Nacional de Resíduos Sólidos; altera a Lei $\mathrm{n}^{0}$ 9.605, de 12 de fevereiro de 1998; e dá outras providências. Brasília, DF, agosto de 2010. Disponível em: http://www2.mma.gov.br/port/conama/legiabre.cfm?codlegi=636 Acesso em: 3 de ago de 2019.

CABRAL, Oswaldo Rodrigues. Nossa Senhora do Desterro. Vol. 1. - Notícias. Florianópolis: Lunardelli, 1979.

CORBIN, Allan. O território do vazio: as praias e o imaginário ocidental São Paulo: Companhia das Letras, 1989

DIÁRIO CATARINENSE. Programa Lixo Zero faz de Florianópolis referência em recuperação de resíduos sólidos. Notícia de 03 de setembro de 2019. Disponível em: https://www.nsctotal.com.br/noticias/programa-lixo-zero-faz-de-florianopolisreferencia-em-recuperacao-de-residuos-solidos. Acesso em 11 de out de 2019.

DOUGLAS, Mary. Pureza e perigo: ensaio sobre a noção de poluição e tabu. Lisboa: Edições 70, 1991.

FLORIANÓPOLIS/CMF. PL 17.506/2018, dispõe sobre a obrigatoriedade da Reciclagem de Resíduos Sólidos Orgânicos no Município de Florianópolis. Florianópolis, 2018. Disponível em: http://velho.cmf.sc.gov.br/proclegis/TextoOriginal/PL_17506_2018_Original.PDF. Acesso em 19 de ago de 2019.

FLORIANÓPOLIS/COMCAP. Evolução da limpeza pública na Capital: Das praias para o forno e o lixão. Prefeitura Municipal de Florianópolis, Florianópolis, 2012. Disponível em: http://www.pmf.sc.gov.br/entidades/comcap/index.php?cms=evolucao + da + limpeza + pu blica+na+capital. Acesso em 04 de out de 2019. 
FLORIANÓPOLIS/PMCS. Plano Municipal de Coleta Seletiva - Produto 6 Versão Preliminar do Plano de Coleta Seletiva. Florianópolis, 2016. Disponível em: http://www.pmf.sc.gov.br/entidades/infraestrutura/index.php?cms=produtos\&menu=15. Acesso em 03 de out de 2019.

FLORIPAMANHÃ. Biguaçu vai proibir entrada do lixo da Capital no aterro. Carlos Damião, para o Notícias do Dia Florianópolis, 16 de dez de 2016. Disponível em: http://floripamanha.org/2016/12/biguacu-vai-proibir-entrada-do-lixo-da-capital-noaterro/. Acesso em 07 de out de 2019.

GLUCKMAN, Max. Análise de uma Situação Social na Zululândia Moderna. In. BIANCO, Bela Feldman (org.). Antropologia das Sociedades Complexas: Métodos. São Paulo: Ed. Global, 1987.

HINCAPIÉ, Liliana G. Para uma Antropologia da Política Pública: dinâmicas da construção de políticas públicas para comunidades afro-colombianas. In: Rev. Pol, Públ., São Luís, v. 19, n. 1, p. 157-171, jan./jun. 2015.

ICMBIO. DECRETO No 875, DE 19 DE JULHO DE 1993: Promulga o texto da Convenção sobre o Controle de Movimentos Transfronteiriços de Resíduos Perigosos e seu Depósito. Disponível em: http://www.icmbio.gov.br/cepsul/images/stories/legislacao/Decretos/1993/dec $875 \quad 199$ 3 convencaobasileia residuospeigosos.pdf Acesso em 28 de set de 2019.

KRENAK, Ailton. 'Vida sustentável é vaidade pessoal', diz Ailton Krenak. [Entrevista concedida a] Fernanda Santana. Correio 24h, Salvador, 25 de jan de 2020.

DE CARVALHO, Rianna. Circuitos ambientalistas e estratégias lixo zero em Florianópolis. Dissertação (mestrado em Antropologia Social). Programa de Pós-Graduação em Antropologia Social -UFRN: Natal, 2020.

DE LIMA, João Samarone Alves e GUIVANT, Julia Sílvia. e-waste - a consequência do consumo global de produtos de tecnologias da informação e comunicação. In: RIAL, Carmen (org.) O poder do lixo: abordagens antropológicas dos resíduos sólidos. Rio de Janeiro: Associação Brasileira de Antropologia, 2016.

DIÁRIO ELETRÔNICO DO MUNICÍPIO DE FLORIANÓPOLIS, Edição No $\mathbf{2 4 8 1}$, Florianópolis/SC, quarta-feira, 17 de julho de 2019, p. 2 e 3. Disponível em: http://www.pmf.sc.gov.br/arquivos/diario/pdf/17_07_2019_18.41.05.76912d946042beb73c29215893 b7a351.pdf Acesso em:19 de set de 2019.

MARQUES, Luiz. Capitalismo e colapso ambiental. Campinas, SP: editora da Unicamp, 2015.

MINISTÉRIO DO MEIO AMBIENTE, Centro de Estudos e Promoção da Agricultura de Grupo, Serviço Social do Comércio. Compostagem doméstica, comunitária e 
institucional de resíduos orgânicos: manual de orientação. Brasília, DF: MMA, 2017. Disponível em: https:/www.mma.gov.br/images/arquivo/80058/CompostagemManualOrientacao_MMA_2017-06-20.pdf Acesso em 30 de set de 2019.

MÜLlER, Glaucia Regina Ramos. A Influência do Urbanismo Sanitarista na Transformação do Espaço Urbano em Florianópolis. Dissertação (mestrado em geografia) Universidade Federal de Santa Catarina - UFSC: Florianópolis, 2002.

$\mathrm{ND}+$. Falta de pagamento impede depósito de lixo no aterro de Biguaçu. Redação ND, Florianópolis 27 de nov de 2013. Disponível em: https://ndmais.com.br/noticias/falta-de-pagamento-impede-deposito-de-lixo-no-aterrode-biguacu/ Acesso em: 08 de out de 2019.

NSC Total. Conheça os vereadores mais votados em Florianópolis nas eleições de 2020. Clarissa Battistella e Lucas Paraizo, Florianópolis, 15 de nov de 2020. Disponível em: $\quad$ https://www.nsctotal.com.br/noticias/vereadores-mais-votados-florianopoliseleicoes-2020 Acesso em: 20 de dez de 2020.

OLIVEIRA, Maria Teresa de; LOPES, Wilson Roberto Cancian. A questão dos resíduos sólidos urbanos e o sistema jurídico brasileiro - caso de Florianópolis. Artigo para disciplina (Pós-Graduação em Direito Ambiental). Universidade Federal de Santa Catarina, Florianópolis, $1997 . \quad$ Disponível em: http://www.pmf.sc.gov.br/arquivos/arquivos/pdf/15_12_2010_11.53.53.ab184b9cd42e5 db8c330364f1b697e7a.pdf. Acesso em 30 de set de 2019.

PÁDUA, José Augusto. Vivendo no Antropoceno: incertezas, riscos e oportunidades. In: OLIVEIRA, Luiz Alberto (org.). Museu do Amanhã. Rio de Janeiro: Edições de Janeiro, 2015. Disponível em: https://museudoamanha.org.br/livro/. Acesso em $14 \mathrm{de}$ março de 2019.

PIAZZA, Walter Fernando. A Colonização de Santa Catarina. $3^{\text {a }}$ edição. Florianópolis: Lunardelli, 1994.

RIAL, Carmen. Mar-de-dentro: a transformação do espaço social na lagoa da Conceição. Dissertação (mestrado em Antropologia Social). Universidade Federal do Rio Grande do Sul - UFRGS: Porto Alegre, 1988.

RIAL, Carmen (org.) O poder do lixo: abordagens antropológicas dos resíduos sólidos. Rio de Janeiro: Associação Brasileira de Antropologia, 2016.

SCHNEIDER, Kamila Guimarães e ALMEIDA, Caroline Soares de. Do lixo ao prato: um estudo sobre a reutilização de resíduos orgânicos a partir da concepção de diferentes classes sociais. In: RIAL, Carmen (org.) O poder do lixo: abordagens antropológicas dos resíduos sólidos. Rio de Janeiro: Associação Brasileira de Antropologia, 2016.

SERRES, Michel. O mal limpo: poluir para se apropriar? Rio de Janeiro: Bertrand Brasil, 2006. 
TSING, Anna Lowenhaupt. Viver nas ruínas: paisagens multiespécies no Antropoceno. Tradução de Thiago Mota Cardoso et al. Brasília: IEB Mil Folhas, 2019.

VAN VELSEN, Jaap. A análise situacional e o método de estudo de caso detalhado. In: BIANCO. Bela Feldman (org.). Antropologia das sociedades contemporâneas: Métodos. São Paulo: Ed. Global, 1987.

Recebido: $27 / 08 / 2020$

Aprovado: $08 / 12 / 2020$ 